DOI: $10.15290 /$ bsl.2021.19.07

Creative Commons License: CC BY-SA 4.0

https://creativecommons.org/licenses/by-sa/4.0/deed.en

\author{
Magdalena Dąbrowska \\ Wydział Lingwistyki Stosowanej \\ Uniwersytet Warszawski \\ e-mail: m.dabrowska@uw.edu.pl \\ ORCID: 0000-0002-4014-4725
}

\title{
Francja oczami podróżopisarzy rosyjskich (Listy Rosjanina podróżujacego po Europie od 1802 do 1806 roku Dmitrija Gorichwostowa)
}

Spod pióra Dmitrija Gorichwostowa (1769-1846) wyszły dwie pozycje podróżopisarskie: Listy Rosjanina podróżującego po Europie od 1802 do 1806 roku (Письма россиянина, путешествовавшего по Европе с 1802 nо 1806 год, 1808) ${ }^{1}$ oraz Zapiski Rosjanina podróżujaceego po Europie od 1824 do 1827 roku (Запискu россиянина, путешествовавшего по Европе с 1824 по 1827 год, 1831-1832)². Oba utwory pozostają znane wąskiemu gronu specjalistów ${ }^{3}$. W przedmowie do pierwszego autor stwierdził, że „Francja bardziej od innych państw zwróciła [jego - dop. M.D.] uwagę i wywołała żywe zainteresowanie przyjaciół" [LR, k.1, s.IV]. Relacja z pobytu w tym kraju wypełniła w całości drugą (z trzech) części utworu oraz obszerne partie pierwszej, w większości po-

\footnotetext{
1 [D. Gorihvostov], Pis'ma rossiânina, putešestvovav̌šego po Evrope s 1802 po 1806 god, kn. 1-3, Moskva 1808. Poszczególne części składowe są określane przez autora jako „Книжки”. Tu i dalej przekład, zarówno tytułów, jak i cytatów, własny - M.D. Kolejne cytaty lokalizuję w tekście głównym, oznaczając je skrótem LR.

2 D. Gorihvostov, Zapiski rossiânina, putešestvovavšego po Evrope s 1824 po 1827 god, kn. 1-2, Moskva 1831-1832. Kolejne cytaty lokalizuję w tekście głównym, oznaczając je skrótem ZR.

3 Tym bardziej warto odnotować ich przywołania w publikacjach spoza ścisłego kręgu prac na temat literatury rosyjskiej. Wzmianka o pierwszym z nich pojawia się w najnowszym zarysie dziejów Warszawy Błażeja Brzostka, bez wskazania nazwiska autora (nieznany „podróżny rosyjski") w kontekście dawnych relacji cudzoziemców o ziemiach polskich. Zob. B. Brzostek, Wstecz, Historia Warszawy do początku, Warszawa 2021, s. 633.
} 
święconej pobytowi na ziemiach niemieckich. W przedmowie do drugiego czytamy, że „Rzym i Neapol szczególnie dostarczyły mu obfitości przedmiotów ciekawych do odnotowania" [ZR, k.1, s.V]. Mimo tej deklaracji oraz czytelnego odesłania do Listów Rosjanina..., zawierających „rozliczne materiały o Francji i Paryżu”, w Zapiskach Rosjanina... są obecne "partie francuskie", zatytułowane - pierwszy - Paryż (z sześcioma podrozdziałami: Pobożność Karola X, Ateneum Paryskie, Wolność druku ksiażek, Handel, Teatry, Niektóre cechy charakterystyczne Francuzów) - oraz - drugi (już bez wyodrębnionych części składowych) - Bouillon. Calais. W zamyśle autorskim drugi utwór miał stać się więc uzupełnieniem pierwszego, opartym, co wynika z przedmów, na tych samych dwóch zasadach ogólnych. W przedmowie do Listów Rosjanina... czytamy, że powodem wyruszenia w podróż po Europie była „bardziej przyjemność niż [...] cel naukowy” [LR, k.1, s.III], natomiast $\mathrm{w}$ przedmowie do Zapisków Rosjanina... autor wyraził zdziwienie popularnością "statystycznych opisów państw i charakterystyk ich narodów" oraz zapowiedział, że "dokładne i naukowe ustalenia nie były zgodne ani ze stanem ducha, ani z celem podróżnika" [ZR, k.1, s.IV]. Z przedmowy do Listów Rosjanina... wynika, że na ich zawartość złożyły się autentyczne listy Gorichwostowa do przyjaciół, których początkowo nie planował on upubliczniać, ale które pod ich wpływem opublikował „prawie bez poprawek i upiększenia" [LR, k.1, s.IV], przedmowa do Zapisków Rosjanina... zawiera zaś deklarację, że „upiększenia i wymysły, [...] wrogie prawdzie, obce były planowi" [ZR, k.1, s.III].

Przebieg podróży tytułowego Rosjanina pozwala mówić o realizacji modelu "podróży objazdowej”, zaczynającej się i kończącej w ojczyźnie podróżnika (w Listach Rosjanina... wyprawa ma początek w Petersburgu i wiedzie na Zachód Europy wzdłuż brzegów Morza Bałtyckiego przez Memel i Königsberg, w Zapiskach Rosjanina... wyjazd następuje z Moskwy i droga przebiega przez Kijów w kierunku południowo-zachodnim) oraz prowadzącej - niczym znana z wcześniejszych czasów „wielka podróż” (Grand Tour) - przez wiele krajów europejskich. Listy Rosjanina... wykazują przynależność raczej do „podróży dokumentalnych” niż „podróży literackich”, jeśli posłużyć się klasyczną klasyfikacją Janiny Kamionki-Straszakowej" ${ }^{4}$, choć można doszukiwać się w nich walorów literackich oraz nawiązań do poprzedników literackich. Pośród nauczycieli Gorichwostowa w zakresie podróżopisarstwa na plan pierwszy wysuwa się Nikołaj Karamzin, autor głośnych Listów podróż-

\footnotetext{
4 Zob. J. Kamionka-Straszakowa, Podróż, w: Słownik literatury polskiej XIX wieku, red. J. Bachórz, A. Kowalczykowa, Wrocław - Warszawa - Kraków 1991, s. 698.
} 
nika rosyjskiego, również zawierających obszerne opisy Francji ${ }^{5}$. Wraz z nim rozpowszechnił się w literaturze rosyjskiej sentymentalizm. Autora Listów Rosjanina... i innych naśladowców dzieła Karamzina Wasilij Sipowski nazwał „pięknoduchami”, od których „często słyszymy nazwisko Karamzina, a jeżeli nie słyszymy, to sami bez trudu pojmiemy, pod czyim wpływem kształtowali się owi młodzi pisarze" ${ }^{6}$. Ze względu jednak na to, że nie dysponujemy wiedzą o genezie i procesie powstawania Listów Rosjanina... (w ogóle nasza wiedza o Gorichwostowie jest nader skromna ${ }^{7}$ ), nie możemy stwierdzić, czy rzeczywiście wyrastają one z autentycznej korespondencji czy też odwołanie się do niej jest ze strony twórcy tylko konwencjonalnym zabiegiem literackim, mającym na celu stworzenie iluzji prawdziwości relacji, zasadne wydaje się potraktowanie ich jako "dzieła literackiego imitującego "nieliterackość»", czyli w taki sam sposób jak Jurij Łotman i Boris Uspienski opisali Listy podróżnika rosyjskiego Karamzina ${ }^{8}$.

W odniesieniu do obrazu Francji w Listach Rosjanina..., które - ze względu na programowo "francjocentryczne" zorientowanie - staną się głównym przedmiotem analizy $\mathrm{w}$ niniejszym artykule, wspomniane na wstępie dwa podstawowe założenia wymagają dodatkowych komentarzy.

Pierwszy dotyczy celu podróży. W przedmowie autor nie poprzestaje na wskazaniu Francji jako głównego - w sensie geograficznym - celu wyjazdu, ale szeroko uzasadnia swój wybór. Francja jest postrzegana jako państwo, w którym niedawno dokonały się i wciąż trwają zmiany polityczne. Chodzi o rewolucję francuską, zniesienie monarchii oraz powołanie I Republiki Francuskiej, przejęcie kontroli w republice przez Napoleona Bonapartego oraz proklamowanie w 1804 roku cesarstwa. Autor traktuje wydarzenia polityczne jako rzutujące na wszystkie sfery funkcjonowania państwa francuskiego oraz jego stosunki z innymi krajami europejskimi. Takie postawienie sprawy pociąga za sobą wprowadzenie innych niż w pozostałych partiach zasad konstrukcyjnych: jeśli relacja z pobytu podróżnika na ziemiach niemieckich przebiega zgodnie z porządkiem chronologicznym, opisuje on to,

5 Zob. m.in. M. Dąbrowska, Obraz Francji w "Listach podróżnika rosyjskiego" Nikołaja Karamzina, „Studia Interkulturowe Europy Środkowo-Wschodniej” 2009, t. 4, s. 36-49.

6 V. Sipovskij, N.M. Karamzin, avtor "Pisem russkogo putešestvennika”, Sankt-Peterburg 1899, s. $457-458$.

7 D. Goperhoeva, Russkaâ literatura putešestvij pervoj poloviny XIX v.: èvoluciâ temy "Rossiâ Zapad”, „Vestnik Burâtskogo Gosudarstvennogo Universiteta” 2018, vyp. 2, s. 97-104.

8 Û. Lotman, B. Uspenskij, „Pis'ma russkogo putešestvennika” i ih mesto v razvitii russkoj kul'tury, v: Û.M. Lotman, Karamzin. Sotvorenie Karamzina. Stat'i i issledovaniâ 1957-1990. Zametki i recenzii, Sankt-Peterburg 1997, s. 526. 
co kolejno znalazło się w zasięgu jego wzroku, to znaczną częścią "listów z Francji” "rządzi” zasada segmentyzacji tematycznej, polegająca na wyodrębnieniu części składowych tematycznie „wyspecjalizowanych”. Są to przy tym nie tylko ustępy, które otrzymały własne tytuły i przypominają rozprawy czy rozbudowane hasła encyklopedyczne na podany w tytule temat (Niektóre uwagi statystyczne o Francji, Rolnictwo, Zwiazki polityczne i ekonomiczne Francji z obcymi państwami, Spojrzenie na literaturę francuska, Wybitni dowódcy francuscy), a w strukturze całego utworu jawią się jako części aneksowe, ale również szereg innych, które - mimo że nie zostały opatrzone tytułami - mają wyraźny profil tematyczny (pierwszą z „rozpraw” poprzedzają fragmenty o kościele i wojsku, a jeszcze wcześniej obecny jest passus o teatrach itp.). Jak już wiemy, z pierwszego rozwiązania pisarz skorzysta (w skromniejszym niż za pierwszym razem) zakresie w Zapiskach Rosjanina... Co więcej, czytelnik Listów Rosjanina... zostaje poinformowany - w przypisie do pierwszego „listu z Paryża" - o rezygnacji w relacji z Francji od porządku chronologicznego, zamieszczeniu listów w innej niż wynikająca $z$ przebiegu trasy kolejności [LR, k.1, s.179]. Równolegle z wiadomościami o współczesnej Francji czytelnik otrzymuje wiedzę - o różnym stopniu szczegółowości - o jej przeszłości, poczynając od czasów starożytnych, przez panowanie Ludwika XV i Ludwika XVI oraz „kosę rewolucyjną" [LR, k.2, s.39], a skończywszy na rządach Napoleona i jego polityce zagranicznej. Ostatni etap dziejów jest najszerzej opisany, również dlatego, że poszczególne decyzje miały wpływ na sytuację samego podróżnika, w końcu konstatującego ze smutkiem, że "nadzieja na szybkie zawarcie pokoju między wrogimi państwami znikła" [LR, k.2, s.225].

Drugi komentarz - wynikający z pierwszego - odnosi się do sfery motywacji i wyborów podróżnika, celu wyjazdu, rozumianego jako odpowiedź na pytanie, po co wyrusza on w te czy inne miejsca. Gdy w przedmowie padają słowa, że celem całego przedsięwzięcia była „bardziej przyjemność niż [...] cel naukowy", później zaś podróżnik wyraża wdzięczność odbiorcom swojej relacji za zwolnienie go z obowiązku przekazywania wiedzy o oglądanych miejscach, uciążliwego i trudnego bez uniknięcia pomyłek i uproszczeń [zob. LR, k.1, s.177-178], a jednocześnie lektura „listów z Francji” utwierdza nas w przekonaniu, że powstały one $\mathrm{z}$ myślą właśnie o przekazaniu wiadomości o tym państwie, ",statystycznych, geograficznych, historycznych, politycznych, filozoficznych" i wszelkich innych, to powstaje odczucie dysonansu, rozminięcia się wstępnych deklaracji i praktyki. To odczucie pogłębia się po zapoznaniu się z klasyfikacją podróżników, zaproponowaną w "liście z Brukseli" [LR, k.1, s.122-123]. Z niego pochodzą słowa o gromadzeniu wiedzy „statystycznej, geograficznej, historycznej, politycznej, filozoficznej" o odwiedzanych miejscach, stanowiącej wyróżnik postawy pierwszej kate- 
gorii podróżników. Drugą tworzą ci, którzy przemieszczają się „dla własnej przyjemności, bez celu, po to, aby zostać podróżnikiem, [...] zgodnie z własnym kierunkiem, zamiarami, zachciankami..." [LR, k.1, s.122-123]. I właśnie do nich narrator zalicza samego siebie, mimo że „listy z Francji” zdają się pokazywać go jako przedstawiciela pierwszej grupy ${ }^{9}$. Gdy jednak podróżnik przyznaje, że dobrze jest wiedzieć, w jakim kierunku „obraca się koło polityczne", ale jednocześnie dokładne śledzenie jego biegu uznaje za zbędne dla wszystkich poza dyplomatami [LR, ks.1, s.180], odczucie dysonansu $\mathrm{w}$ jego postawie wyraźnie się zaciera. W jeszcze większym stopniu słabnie ono wtedy, gdy dowiadujemy się, czego narrator oczekuje po samej podróży: pierwszy odcinek przejazdu przez Francję - w kierunku Lille - zaplanował z myślą o „pięknym czasie, malowniczych miejscach, wygodnych dyliżansach, wesołych współtowarzyszach, uczynnych oberżystach, czyniących podróż przyjemną" [LR, k.1, s.158]. Podróżnik nie porzuca zatem swojej "filozofii podróży”, ale modyfikuje ją pod wpływem potrzeby chwili i okoliczności. Albo inaczej: realizuje oświeceniowe hasło połączenia "przyjemnego z pożytecznym”, raz wysuwając na plan pierwszy „przyjemność”, innym razem "pożytek".

Powyższe wstępne ustalenia wypada uzupełnić o dwa następne generalia, dotyczące trasy i czasu przejazdu tytułowego Rosjanina przez Francję. Szlak podróżny prowadzi przez Lille, Reims, Paryż, który wraz z okolicznymi miejscowościami jak Wersal czy Fontainebleau wyrósł na główny przedmiot zainteresowania, a także Ermenonville (wzmiankowanych miejsc jest oczywiście więcej). Podróżnik przemieszcza się drogą lądową, powozami o różnej nazwie, konstrukcji, komforcie jazdy i przeznaczeniu (avec le courier de la malle [LR, k.1, s.167] i in.). Jeżeli wybiera szlak wodny, to nie z rzeczywistej potrzeby, ale wyłącznie dla rozrywki, po to, aby „uczynić [...] przejażdżkę przyjemniejszą", jak pisze o rejsie po Sekwanie [LR, k.1, s.199]. Co ciekawe, przyznaje się także do pobierania lekcji pływania w głównej rzece Francji [zob. LR, k.1, s.213]. Czas podróży jest możliwy do określenia tylko w przybliżeniu: zgodnie z tytułem wykorzystana jest forma epistolarna, ale nagłówki listów nie są datowane, zdarza się jednak narratorowi sygnalizować upływ czasu (gdy pisze o spacerze po ogrodach Wersalu w trzydziestostopniowym upale, podarunkach noworocznych na straganach koło

9 Pomysł przeglądu typów podróżników mógł zrodzić się pod wpływem Podróży sentymentalnej przez Francję $i$ Włochy Laurence'a Sterne'a, przy czym wykorzystał go nie tylko Gorichwostow, ale także wcześniejszy od niego podróżopisarz rosyjski Michaił Murawjow. Zob. M. Dąbrowska, The Idle Traveller? O koncepcji podróżnika w twórczości Michaita Nikiticza Murawjowa, w: Inny w podróży, t. 1 (Literackie świadectwa podróży na przestrzeni wieków), red. O. Weretiuk, M. Rabizo-Birek, Rzeszów 2017, s. 120-130. 
Palais-Royal itp. [zob. LR, k.1, s.203, k.2, s.51]). Na początku części trzeciej Listów Rosjanina... mowa jest ponadrocznym pobycie w Paryżu [LR, k.3, s.3], w Zapiskach Rosjanina... czytamy o spędzonych tutaj czternastu miesiącach [ZR, k.1, s.V]. Pobyt we Francji jawi się jak ciąg miniaturowych „podróży objazdowych": z Reims podróżnik wyprawia się do okolicznych winnic, by następnie wrócić do miasta i wyjechać do Paryża, dogodną bazą wypadową po okolicy staje się również sama stolica. Tytułowy Rosjanin powtarza obiegową opinię, że "do tego, by dogłębnie poznać jakieś państwo, potrzebne są duże środki i długi pobyt w nim" [LR, k.1, s.177], nie dopowiada jednak, czy dla niego pobyt w Paryżu okazał się wystarczający. Dokonywane przez niego przeliczenia cen (noclegów w hotelu, usług, posiłków itp.) z miejscowej waluty na ruble nie pozostawiają wątpliwości natomiast co do tego, że duże zasoby finansowe nie były niezbędne, jedno z nich zakończył bowiem słowami „z tego możecie wnioskować, że utrzymanie tutaj jest niedrogie” [LR, k.1, s.181].

Zgodnie z zapowiedzią tytułową, celem niniejszego artykułu jest nakreślenie obrazu kraju nad Sekwaną utrwalonego w wymienionym utworze Gorichwostowa. Oznacza to odpowiedź na pytania, jak w świetle Listów Rosjanina... przedstawia się on z punktu widzenia wkładu w cywilizację europejską oraz jaki jest jego odbiór przez przybysza z zagranicy. Innymi słowy, chodzi o wskazanie miejsc, które podróżnik uznał za ważne oraz które pobudziły w nim emocje (właśnie „oraz", nie zaś „lub”, ponieważ szlaki na intelektualnej i emocjonalnej mapie Francji bynajmniej nie biegną osobno, lecz krzyżują się i często pokrywają ze sobą). Kluczem do zrozumienia pierwszej kwestii wydaje się porównanie Francji z ziemiami niemieckimi: „nie szukaj [...] niemieckiej głębi myśli, metafizycy i psychologowie nie są tu w modzie" [LR, k.2, s.49]. Za punkt wyjścia dociekań w drugiej sprawie mogą posłużyć zamykające (jeśli nie liczyć notatki w postscriptum) pierwszy list części drugiej rozważania o naturze przeżyć ludzkich oraz ich źródle, którym początek dało pytanie „czy myślicie [...], że zobaczyłem, usłyszałem i wykorzystałem coś nowego, wyjątkowego, niezwykłego?" i zdecydowana odpowiedź „Nie! widziałem to, co zwykłe: piękno Natury i Sztuki, którego wlewało się $\mathrm{w}$ chwili tej bezpośrednio do mojego serca i wypełniało rozkoszą całe me jestestwo" [LR, k.2, s.8]. Jeśli w tej wypowiedzi podróżnik stawia naturę i sztukę obok siebie, traktuje je na równi, to wcześniej - we wzmiance o drzewach ze ściętymi wierzchołkami i kuliście uformowanymi gałęziami, widzianymi na drodze z Memla do Königsberga - pisał o wyższości natury i swoim większym przywiązaniu do niej niż do sztuki. Opisy Francji należy rozpatrywać więc nie w sposób wyizolowany, lecz w powiązaniu z pozostałymi częściami Listów Rosjanina..., szczególnie tymi, które je poprze- 
dzają. Na osobne odnotowanie zasługują porównania Francji z Rosją, co warte podkreślenia, nie zawsze wypadające na korzyść państwa nad Sekwaną, by przywołać wzmianki o paryskich nabrzeżach, które, w przekonaniu tytułowego Rosjanina, „nie mogą się równać z petersburskimi” [LR, k.1, s.208] oraz sztuce baletowej, we Francji odznaczającej się co prawda „kunsztem tanecznym, wyrazistym przedstawieniem charakterów", ale jednak ustępującej rosyjskiej, "porażającej [...] widza niespodziewanym blaskiem wspaniałością i różnorodnością scen, skalą i pompatycznością" [LR, k.2, s.85].

Do refleksji nad naturą ludzkich przeżyć skłonił podróżnika widok zabawy w Saint-Cloud, tańców w parku, fontann i iluminacji. Zwiedzanie Paryża zaczął od Palais-Royal, następnie przeszedł przez Nowy Most i plac z pomnikiem konnym Henryka IV, widział Luwr, Ogród Luksemburski i znajdujący się w nim pałac, Pałac Wersalski, również z ogrodem, katedrę Notre-Dame, bramy w formie łuków triumfalnych Saint-Denis i Saint-Martin, udał się do biblioteki, obserwatorium, kościołów, teatrów i muzeów. W zbiorach Luwru zwrócił uwagę na posąg Wenus Medycejska oraz obraz Jacquesa-Louisa Davida Porwanie Sabinek, odtworzył strukturę muzeum (podział na sale), opisał wystrój wnętrz. W Fontainebleau obejrzał pałac i przemierzył otaczający miasto kompleks leśny. Odwiedzane miejsca i obejrzane obiekty tworzą bardzo długą listę. Nie trzeba wymieniać ich wszystkich, aby sformułować główne wnioski.

Dwa pierwsze łączą się ze sobą. Na pobyt tytułowego Rosjanina nad Sekwaną złożyły się raczej spotkania z miejscami i obiektami niż z ludźmi, a wśród oglądanych miejsc i obiektów znalazły się w większości takie, do których zwyczajowo kierowali kroki przybysze z zagranicy. W pierwszej kwestii nie chodzi przy tym o codzienne rozmowy z Francuzami, wizyty towarzyskie albo kontakty z urzędnikami (te ostatnie niekiedy bywały bardzo uciążliwe), gdyż takich nie brakuje, ale o spotkania $z$ wybitnymi osobistościami życia społecznego, kulturalnego i literackiego, w tych i wcześniejszych czasach stanowiącymi stały punkt programu podróży po Europie. Takich ambicji „Rosjanin podróżujący po Europie” nie miał i to różniło go od innych „podróżujących po Europie”, którzy, jak pisał Antoni Mączak, odwiedzali ludzi sławnych nawet wtedy, gdy „nie mieli im nic do powiedzenia ani nie potrafili zrozumieć ich dzieł" ${ }^{10}$. Można przypuszczać jednak, że gdyby spotkał się on z którąś z wielkich postaci, to słowa badacza pasowałyby także do niego. Pośrednio można to wywnioskować z opisu pobytu w Ermenonville, podparyskiej miejscowości, w której zmarł i został pochowany Jean-

10 Zob. A. Mączak, Peregrynacje. Wojaże. Turystyka, Warszawa 1984, s. 139. 
-Jacques Rousseau. Pobyt tutaj jest spotkaniem tylko z miejscem śmierci tego wybitnego filozofa i pisarza, nie zaś pretekstem do wypowiedzenia się o jego dziełach. Wypada podkreślić jednak, że autorowi Julii, czyli Nowej Heloizy podróżnik poświęcił zdecydowanie więcej uwagi niż pozostałym przedstawicielom kultury francuskiej. Wprawdzie w zarysie dziejów literatury francuskiej - jak wiemy, jednym z kilku „wyspecjalizowanych” tematycznie passusów Listów Rosjanina... o kształcie rozpraw czy haseł encyklopedycznych - Rousseau została poświęcona zaledwie krótka notka, podobnie jak Wolterowi czy Monteskiuszowi, to relacja z Ermenonville powoduje, że pisarz ten wydaje się czytelnikom lepiej znany od innych. I drugi wniosek, który można by ująć też $\mathrm{w}$ taki sposób: podróż tytułowego Rosjanina prowadzi przez miejsca stale odwiedzane i szeroko opisywane przez gości Francji, przebiega szlakiem „wydeptanym” przez poprzedników i „wyeksploatowanym” pod ich piórami. Z tego punktu widzenia "Rosjanin podróżujący po Europie” wydaje się w pełni typowym "produktem” swojej epoki. Skoro jednak poprzednicy nie tylko byli, ale i pozostawili po sobie relacje z pobytu, rodzi się pytanie, czy podróżnik „widział [...] to, co [...] widział” czy raczej „widział [...] to, o czym [...] czytał"? , jak sformułowała je Hana Voisine-Jechova ${ }^{11}$. Jednoznaczna odpowiedź na nie jest trudna, by nie rzec, iż w odniesieniu do całości Listów Rosjanina... niemożliwa do udzielenia, niemniej znajdujemy w tym utworze fragmenty, co do których możemy przypuszczać, iż powstały pod wpływem czy z inspiracji cudzego tekstu. Za przykład ponownie może posłużyć relacja z pobytu w Ermenonville, wykazująca zbieżność - na poziomie zarówno ogólnego zamysłu, jak i szczegółowych rozwiązań kompozycyjnych i treściowych - $\mathrm{z}$ analogicznym ustępem $\mathrm{w}$ Listach podróżnika rosyjskiego Karamzina ${ }^{12}$. Jest to jeden $z$ tych fragmentów, którego mogły dotyczyć zacytowane wcześniej słowa Sipowskiego. Spod pióra Karamzina i Gorichwostowa wychodzi opis Ermenonville jako rozległego kompleksu muzealnego, w którym pamięć o autorze Emila, czyli $O$ wychowaniu przekazywana jest równolegle na dwóch poziomach: oficjalnym, instytucjonalnym oraz prywatnym, przez okolicznych mieszkańców. „Podróżnik rosyjski” Karamzina i „Rosjanin podróżujący po Europie" Gorichwostowa oglądają pomnik z napisem „Ici repose l'homme de la nature et de la vérité" oraz dewizą Rousseau „Vitam impendere vero" i przedmioty, które miejscowa ludność uważa za używane

11 H. Voisine-Jechova, Podróż jako doświadczenie, marzenie oraz poszukiwanie sensu egzystencji w prozie 1760-1820, w: Dziedzictwo Odyseusza. Podróż, obcość i tożsamość, identyfikacja, przestrzeń, red. M. Cieśla-Korytowska, O. Płaszczewska, Kraków 2007, s. 124.

12 Zob. N. Karamzin, Pis'ma russkogo putešestvennika, v: N. Karamzin, Sočineniâ v dvuh tomah, t. 1 (Avtobiografiâ. „Pis'ma russkogo putešestvennika”. Povesti), Leningrad 1984, s. 408-414. 
niegdyś przez pisarza. Jak zauważa Voisine-Jechowa, „konfrontacja pośredniej informacji z bezpośrednią percepcją [...] prowadzi do poszerzenia horyzontu wrażeń, rzeczywistość widzi się w powielonym odbiciu"13. Należy dodać jednak, że odbicie to nie jest jedynie powielone, ale również zmienione, zmodyfikowane, przede wszystkim dlatego, że bezpośredni kontakt z miejscem odsłonił upływ czasu i zmiany nim wywołane. „Z wielką przyjemnością przemierzałem [...] Ermenonville, każdy szczegół w nim przyjemnie zajmował mnie" - pisał "Rosjanin podróżujący po Europie”, ale zaraz dodawał, że jest coś, co wywoływało w nim smutek, to mianowicie, że oglądane miejsce „utraciło swój dawny blask” [LR, k.2, s.38]. Czerpanie przyjemności $\mathrm{z}$ obcowania $\mathrm{z}$ miejscem i jednocześnie poczucie smutku prezentuje go jako melancholika. Także pod tym względem wydaje się on "dzieckiem” swojej epoki, która zapisała się w dziejach kultury europejskiej jako czasy „uroków smutku” 14 i „nostalgii, siostry melancholii” ${ }^{15}$. Jeśli więc opis Ermenonville w Listach Rosjanina... wyrósł z Listów podróżnika rosyjskiego Karamzina, to odzwierciedla on nowe doznanie tego miejsca.

Trzeci wniosek jest następujący: jeżeli szukać słowa kluczowego opisów miejsc i obiektów we Francji, to będzie nim z pewnością "gust". Właśnie jako „ludzi gustu" podróżnik postrzega Francuzów, gdy tymczasem Niemcy, co warto powtórzyć raz jeszcze, są, według niego, „ludźmi myśli". Oto jak charakteryzuje pierwszych: „Francuzi, wymagający w kwestii gustu, obiektywni $\mathrm{w}$ ocenach, nie pozostawią złego bez wyśmiania, z zachwytem pochwalą co dobre, wartościowemu oddadzą należną sprawiedliwość" [LR, k.2, s.64]. Ocenę w kategoriach "gustowny - niegustowny" zaczął szeroko stosować on sam. "Wzorem gustu” nazwał kolumnadę w Luwrze, ale przyznał jednocześnie, że nie zrobiła ona na nim takiego wrażenia, jakiego się spodziewał [LR, k.1, s.175]; „nie powiem, że dobrym gustem [...] wprawiła mnie w zachwyt" - pisał o rezydencji w Saint-Cloud [LR, k.1, s.199]. Podróżnik nie jest jednak konsekwentny w swoich sądach: raz skrytykował kolumnadę Luwru, innym razem zaliczył ją do „najlepszych dzieł architektury starożytnej i nowożytnej", przy okazji przypominając jej współprojektanta - Claude'a Perraulta [LR, k.2, s.182]. We Francji znalazły się też miejsca, które wywołały w podróżniku mieszane uczucia: tak zdarzało mu się postrzegać Paryż, którego różnorodność sprawiała, że miał trudności ze zrozumieniem „myśli,

13 H. Voisine-Jechova, Podróż jako doświadczenie, marzenie oraz poszukiwanie sensu egzystencji w prozie $1760-1820$, s. 125.

14 Zob. M. Gołaszewska, Uroki smutku. Szkic z pogranicza estetyki i filozofii człowieka, Wrocław 1992.

15 Zob. M. Zaleski, Nostalgia, siostra melancholii, „Res Publica Nowa” 1994, nr 6, s. 7-12. 
które [...] w nim powstały” i nie był w stanie "należycie ocenić tego, co widział owego dnia" [LR, k.1, s.176]. Wszelkie subiektywne oceny, wyznania podróżnika, że coś go poruszyło, zachwyciło, rozczarowało, zdziwiło albo wprowadziło $\mathrm{w}$ jakikolwiek inny stan emocjonalny, wpływają na ożywienie toku narracji, miejscami dość monotonnego przez umieszczenie w nim długiego ciągu nazw miejsc i obiektów.

Taką monotonną rzeczowością charakteryzuje się - jeśli szukać przykładu spoza opisów topografii i architektury miejskiej - podsumowanie passusu o towarach eksportowych Francji: „handel [...] opiera się na winach, wódkach, jedwabiu, suknie, koronkach, płótnach, oliwie (prowansalska słynie jakością w całej Europie), modzie [tzn. ubiorach - M.D.], wyrobach ze złota i srebra, pachnidłach, książkach" [LR, k.2, s.108]. To jednak nie handel czy opisane w innych miejscach rolnictwo i sztuka wojenna, lecz kultura i literatura są głównymi wizytówkami Francji i przede wszystkim z myślą o nich - mimo deklarowanej chęci poznania nowego porządku politycznego - podróżnik wybrał się do tego kraju. Tak brzmi wniosek czwarty, pośrednio zapowiedziany przez poprzednie. Do najciekawszych fragmentów Listów Rosjanina... nieprzypadkowo należy porównanie etapów rozwoju intelektualnego Francji, wypełniające znaczną część rozprawy Rzut oka na literature francuską: na wiek XVII przypadł rozwój literatury, stulecie XVIII przyniosło jej doskonalenie oraz rozwój nauki, wiek XIX zapowiada się jako okres „starości, schyłkowości, a być może i końca literatury francuskiej” i podobnego stanu nauki, w której miejsce Francuzów mogą zająć przedstawiciele innych narodów, dotąd słabo zaznaczający swoją obecność na tym polu [zob. LR, k.2, s.184, 208-209]. Do Francji należą zatem przeszłość i teraźniejszość, jej przyszłość rysuje się mgliście i niepewnie.

Na zakończenie warto sformułować jeszcze wnioski dotyczące perspektyw badawczych. Francja wielokrotnie stawała się przedmiotem zainteresowania podróżopisarzy rosyjskich różnych czasów. Najważniejszy poprzednik Gorichwostowa - Nikołaj Karamzin, autor Listów podróżnika rosyjskiego - został wymieniony. W gronie tym znaleźli się też Paweł Sumarokow, twórca Przechadzki za granice (1821), czy Paweł Annienkow, spod pióra którego wyszły Listy paryskie $(1848)^{16}$. Najpilniejszą potrzebą wydaje się uzupełnienie tego korpusu tekstów o nowe pozycje i przeprowadzenie porównania zawartego w nich obrazu Francji, a w szczególności jej stolicy. Wydobyte z zapo-

16 Zob. N. Belova, "Parižskij tekst” v russkoj literature pervoj poloviny XIX veka. (K postanovke problemy), „Vestnik Ûgorskogo Gosudarstvennogo Universiteta” 2011, vyp. 1(20), s. 71-77; N. Belova, Imagolog Pariža v russkih travelogah pervoj poloviny XIX veka, "Vestnik ugrovedeniâ" 2012 , t. 8 , no. 1 , s. $18-26$. 
mnienia teksty podróżopisarskie mogą zostać poddane wieloaspektowemu odczytaniu, opierającemu się na różnych ujęciach metodologicznych (komparatystyka o zorientowaniu genetycznym i typologicznym, imagologia, geokulturologia, urban studies i in.). Celem nadrzędnym wydaje się jednak wpisanie ich w perspektywę relacji „Wschód - Zachód” w kulturze europejskiej, łącznie z wprowadzeniem kategorii "rosyjskiego Europejczyka”, nakreślenie w oparciu o nie „mapy cywilizacyjnej” Europy XIX wieku. Sformułowanie „mapa cywilizacyjna" nawiązuje do podtytułu poświęconej stuleciu poprzedniemu głośnej książki Larry'ego Wolffa ${ }^{17}$, w której jednak nacisk położony jest na postrzeganie Europy Wschodniej przez przedstawicieli Zachodu, gdy tymczasem utwory, o których tu jest mowa, rzucają światło na postrzeganie Europy Zachodniej przez przybyszów ze Wschodu.

\section{Bibliografia}

Belova N. (2011), „Parižskij tekst” v russkoj literature pervoj poloviny XIX veka. (K postanovke problemy), „Vestnik Ûgorskogo Gosudarstvennogo Universiteta”, vyp. 1(20), s. 71-77.

Belova N. (2012), Imagolog Pariža v russkih travelogah pervoj poloviny XIX veka, „Vestnik ugrovedeniâ", t. 8, no. 1, s. 18-26.

Brzostek Błażej (2021), Wstecz. Historia Warszawy do początku, Warszawa: Muzeum Warszawy.

Dąbrowska Magdalena (2009), Obraz Francji w "Listach podróżnika rosyjskiego" Nikotaja Karamzina. „Studia Interkulturowe Europy Środkowo-Wschodniej”, t. 4, s. 36-49.

Dąbrowska Magdalena (2017), The Idle Traveller? O koncepcji podróżnika w twórczości Michaiła Nikiticza Murawjowa, w: Inny w podróży, t. 1 (Literackie świadectwa podróży na przestrzeni wieków), red. O. Weretiuk, M. Rabizo-Birek, Rzeszów: Wydawnictwo Uniwersytetu Rzeszowskiego, s. 120-130.

Gołaszewska Maria (1992), Uroki smutku. Szkic z pogranicza estetyki i filozofii człowieka, Wrocław: Zakład Narodowy imienia Ossolińskich.

Goperhoeva Dar'â (2018), Russkaâ literatura putešestvij pervoj poloviny XIX v.: èvolûciâ temy "Rossiâ - Zapad”, „Vestnik Burâtskogo Gosudarstvennogo Universiteta”, vyp. 2, s. 97-104.

[Gorihvostov Dmitrij] (1808), Pis'ma rossiânina, putešestvovavšego po Evrope s 1802 po 1806 god, kn. 1-3, Moskva: V Universitetsko tipografii.

Gorihvostov Dmitrij (1831-1832), Zapiski rossiânina, putešestvovav̌šgo po Evrope s 1824 po 1827 god, kn. 1-2, Moskva: V tipografii Knâzâ L'vova.

17 Zob. L. Wolff, Wynalezienie Europy Wschodniej. Mapa cywilizacji w dobie Oświecenia, przeł.

T. Bieroń, Kraków 2020. 
Kamionka-Straszakowa Janina (1991), Podróż, w: Słownik literatury polskiej XIX wieku, red. J. Bachórz, A. Kowalczykowa, Wrocław - Warszawa - Kraków: Zakład Narodowy imienia Ossolińskich, s. 698-703.

Karamzin Nikolaj (1984), Pis'ma russkogo putešestvennika, v: N. Karamzin, Sočineniâ $v$ douh tomah, t. 1 (Avtobiografiâ. "Pis'ma russkogo putešestvennika”. Povesti), Leningrad: Hudožestvennaâ Literatura, s. 55-504.

Lotman Urij, Uspenskij Boris (1997), „Pis'ma russkogo putešestvennika” $i$ ih mesto vrazvitii russkoj kul'tury, v: Û.M. Lotman, Karamzin. Sotvoreniekaramzina. Stat'i i issledovaniâ 1957-1990. Zametki i recenzii, Sankt-Peterburg: Iskusstvo - SPB, s. 484-564. Mączak Antoni (1984), Peregrynacje. Wojaże. Turystyka, Warszawa: Czytelnik.

Sipovskij Vasilij (1899), N.M. Karamzin, avtor "Pisem russkogo putešestvennika”, Sankt-Peterburg: Tipografiâ Imp. Akad. Nauk.

Voisine-Jechova Hana (2007), Podróż jako doświadczenie, marzenie oraz poszukiwanie sensu egzystencji w prozie 1760-1820, w: Dziedzictwo Odyseusza. Podróż, obcość i tożsamość, identyfikacja, przestrzeń, red. M. Cieśla-Korytowska, O. Płaszczewska, Kraków: Universitas, s. 115-130.

Wolff Larry (2020), Wynalezienie Europy Wschodniej. Mapa cywilizacji w dobie Oświecenia, przeł. T. Bieroń, Kraków: Międzynarodowe Centrum Kultury.

Zaleski Marek (1994), Nostalgia, siostra melancholii. „Res Publica Nowa”, nr 6, s. 7-12.

\title{
France in the Eyes of the Russian Travel Writers \\ (The Letters of Russian Travelling across Europe from 1802 to 1806 by Dmitry Gorikhvostov)
}

\begin{abstract}
The paper presents the findings of the research in the field of the Russian and French literary connections in the early 19th century (travels of the Russians to France, the picture of Germany in the Russian documentary and literary travel). The material for the study is based on The Letters of the Russian Travelling across Europe from 1802 to 1806 by Dmitry Gorikhvostov (parts 1-3, Moscow 1808). The interpretive context is the travel literature by Nikolay Karamzin (The Letters of the Russian Traveller, ed. 1801) and Gorikhvostov (The Notes of Russian Travelling across Europe from 1824 to 1827, 1831-1832). The Gorikhvostov's work is discussed from three perspectives: 1. the purposes of the travel to France and the concept of the traveller; 2. the description of France (travel itinerary: Lille - Reims - Paris - Fontainebleau - Ermenonville etc.: museums, artworks, architecture, places connected with J. J. Rousseau, nature; a short story of the French literature); 3. the traveller's attitude to France.
\end{abstract}

Keywords: travel literature, travel, France, Russia, Dmitry Gorikhvostov, Nikolay Karamzin 